TAPROBANICA, ISSN 1800-427X. August, 2014. Vol. 06, No. 02: pp. 90-99, pls. 7, 8.

(C) Research Center for Climate Change, University of Indonesia, Depok, Indonesia

\& Taprobanica Private Limited, Homagama, Sri Lanka

http://www.sljol.info/index.php/tapro

\title{
MELITTOPHILY AND MALACOPHILY IN Ipomoea pes-caprae (CONVOLVULACEAE)
}

\section{A. J. Solomon Raju ${ }^{1,2}$, P. Suvarna Raju ${ }^{1}$ and K. Venkata Ramana ${ }^{1}$}

\footnotetext{
${ }^{1}$ Department of Environmental Sciences, Andhra University, Visakhapatnam 530003, India

${ }^{2}$ E-mail: ajsraju@yahoo.com ${ }^{1}$
}

\begin{abstract}
Ipomoea pes-caprae is a mangrove associate often found along shorelines. It flowers during AugustFebruary and is hermaphroditic and an obligate out-crosser due to self-incompatibility. It is both melittophilous and malacophilous. The natural fruit set rate is less than $10 \%$ probably due to the wastage of pollen in self-pollination, the ephemeral nature of flowers, predation, and nutrient requirements. Seeds are impermeable to water and germinate readily if they are covered and abraded by sand; those exposed to seawater rot and subsequently perish. The low natural fruit set rate, the mortality of seeds and seedlings due to rotting, burial by sand, space constraint, and shading by established plants appear to be regulating the population size of I. pes-caprae. The plant also propagates vegetatively through the expansion of branches that are broken into fragments by storm waves, transported by water, and then washed onshore into new locations.
\end{abstract}

Keywords: creeper, mangrove associate, post-zygotic self-incompatibility, vegetative propagation

\section{Introduction}

Convolvulaceae Juss. are a family of about 60 genera consisting of approximately 1650 species. The Latin name of the family "convolvere", meaning "to wind", came from the winding nature of the stems. Most of the species are herbaceous vines while others are trees, shrubs or herbs. The leaves and starchy, tuberous roots of certain species are used as foodstuffs while others are exploited for their medicinal value (Britta et al., 1999; Steiner et $a l ., 2006)$. The family is primarily pollinated by bees but there are also documented instances of pollination by hawk moths, birds and bats (Willmott \& Burquez, 1996; Austin, 1997). Apart from these pollination syndromes, malacophily has also been reported to be functional and reliable in Volvulopsis nummularia (L.) Roberty (Sarma et al., 2007). In this context, Austin (1997) stated that the discovery of malacophily in this species was a novel addition to pollination syndromes prevailing in the family. In general, pollination 
by snails is a rare and infrequent phenomenon; so far it has been reported in a few species of other families such as Rohdea japonica (Thurb.) Roth, Philodendron pinnatifidum (Willd.) Schott, Colocasia odora (Lindl.) Brongn., Calla palustris L., Lemna minor L., Chrysosplenium alternifolium L., and Phragmipedium caudatum (Lindl.) Rolfe (Pammel \& King, 1930; McGregor, 1976; Atwood, 1982).

In Convolvulaceae, the genus Ipomoea L. consists of about 500 warm-climate trees, shrubs, and twining or trailing herbaceous plants with funnel-shaped flowers. Members of the genus occur throughout the tropical and subtropical regions of the world. The generic name is derived from the Greek words "ips" meaning "worm or "bindweed" and "homoios" meaning "resembling", both referring to the twining habit of the species. Ipomoea is an important genus due to its uses as ornamentals, food crops, food additives, and vulcanization of its latex to rubber and laxatives (Austin, 2004). Despite the importance of Ipomoea, only a few of its species have been studied with reference to their sexual reproduction in relation to pollination syndromes and pollinators. Maimoni-Rodella \& Yanagizawa (2007) reported that $I$. cairica (L.) Sweet, I. grandifolia (Dammer) O'Donell, and I. nil (L.) Roth exhibit promiscuous and opportunistic features in their flowers and are primarily melittophilous. Hull-Sanders et al. (2005) reported that $I$. hederacea Jacq. var. integriuscula A. Gray exhibits mixed mating system and are primarily melittophilous and supplemented by sphingophily and psychophily. The flowers are pollinated when they are open and the morphology ensures pollination by forcing the anthers to glide over the stigmas as the flower closes. In effect, the auto-pollination gives reproductive assurance to the plant. Suvarna Raju et al. (2013) reported that sphingophily and partially melittophily are the pollination syndromes in the mangrove associate, I. tuba (Schltdl.) G. Don in which a mixed breeding system is functional. These reports indicate that the studied Ipomoea species are primarily melittophilous and also pollinated by hawk moths and butterflies. With this background, I. pes-caprae (L.) R. Br., a mangrove associate has been studied for its pollination ecology due to its important role in stabilizing the estuarine banks and shorelines.
Further, the plant is also used for the treatment of swelling in different parts of the body caused by wind abrasions, skin diseases, and inflammation caused by jellyfish allergy. Seed is used for the treatment of fatigue (Ravindran et al., 2005). The main objectives of this paper are to find out the pollination syndrome and breeding system of I. pes-caprae through which it expands its population and distribution range.

\section{Materials and Methods}

Study site: The Coringa mangrove wetland lies between $16^{\circ} 30^{\prime}-17^{\circ} 00^{\prime} \mathrm{N}$ and $82^{\circ} 10^{\prime}-80^{\circ} 23^{\prime} \mathrm{E}$. It is located in the delta of the East Godavari District; it is created by the river Godavari which is $1,330 \mathrm{~km}$ long, the second longest river in India. Freshwater flows into the mangrove wetlands of the Godavari delta for a period of six months with the peak flow normally occurring during July to September, coinciding with the southwest monsoon season. During this period the entire delta, including the mangrove wetland is submerged under freshwater, since penetration of sea water is completely blocked by the large amount of incoming freshwater. Brackish water condition prevails from October to February and sea water dominates the entire mangrove wetland from March to May due to absence of freshwater discharge.

\section{Floral presentation and reproductive traits:} Field investigations and experiments were conducted on Ipomoea pes-caprae during the period from February 2011 to October 2013. The details of flower morphology such as flower sex, shape, size, colour, odour, sepals, petals, stamens, and ovary were described. Anthesis was initially recorded by observing ten marked mature buds in the field. Later, the observations were repeated five times on different days, each day observing twenty marked mature buds to ascertain an accurate anthesis schedule. The same marked mature buds were followed to obtain the time of anther dehiscence. The presentation pattern of pollen was also investigated by recording how anthers dehisced, this being confirmed by observing the anthers under a 10x hand lens. The flower life was recorded by marking twenty just open flowers and following them until fall off. Twenty mature but undehisced anthers were collected from five randomly chosen plants and placed in a Petri dish. Later, over time a single anther was taken out and placed on a clean 
microscope slide $(75 \times 25 \mathrm{~mm})$ and dabbed with a needle in a drop of lactophenol-anilineblue. The anther tissue was then observed under the microscope for pollen, if any, and if pollen grains were not there, the tissue was removed from the slide. The pollen mass was drawn into a band, and the total number of pollen grains was counted under a compound microscope (400x). This procedure was followed for counting the number of pollen grains in each anther collected. Based on these counts, the mean number of pollen produced per anther was determined. The mean pollen output per anther was multiplied by the number of anthers in the flower to obtain the mean number of pollen grains per flower. The characteristics of pollen grains were also recorded. The pollenovule ratio was determined by dividing the average number of pollen grains per flower by the number of ovules per flower. The value thus obtained was taken as pollen-ovule ratio (Cruden, 1977). $\mathrm{H}_{2} \mathrm{O}_{2}$ test as detailed by Dafni et al. (2005) was followed to determine the period of stigma receptivity. The presence of nectar was determined by observing fifty mature buds and open flowers collected at random from ten plants. Individual volumes of nectar were recorded for 25 flowers and then the average volume of nectar per flower was determined and expressed in $\mu l$. The flowers used for this purpose were bagged at mature bud stage, opened after anthesis and nectar was squeezed into a micropipette to measure the volume of nectar. Nectar sugar concentration was also simultaneously determined using a Hand Sugar Refractometer (Erma, Japan).

Breeding system: Fifty flowers each from ten randomly selected plants were used for each mode of breeding system. The flowers were emasculated prior to anther dehiscence and bagged for fruit set through apomixis. The stigmas were pollinated manually with the pollen of the same flower by using a brush; they were bagged for fruit set through manipulated autogamy. Other flowers were fine-mesh bagged without hand pollination for fruit set through spontaneous autogamy. Emasculated flowers were hand-pollinated with the pollen of a different flower on the same plant; they were bagged and followed for fruit set through geitonogamy. Other emasculated flowers were pollinated with the pollen of a different individual plant and bagged for fruit set through xenogamy. All of these modes of pollination were followed for one month to calculate the percentage of fruit set in each mode. Two hundred flowers in different flowering patches were tagged prior to anthesis and followed for fruit and seed set rate in openpollinations. Fruit maturation period, fruit dehiscence, seed dispersal, and establishment were observed in detail.

Observation and collection of floral foragers:

The foragers included bees, a wasp, and a snail. They were observed carefully for ten hours in a day for 15 days in different weeks during the flowering season. The hourly foraging visits of each bee species and the wasp were recorded on ten different days for which $2 \times 2 \mathrm{~m}$ flowering patch was selected. The data obtained were used to calculate the percentage of foraging visits made by each species per day and also to calculate the percentage of foraging visits of bees and wasps per day. Simultaneously, the bees and the wasp were observed for their foraging behavior such as mode of approach, landing, probing behaviour, the type of forage they collected, and how they contacted essential organs for pollination. These insects were captured from the flowers during 10:00-12:00 $\mathrm{h}$ on five different days for pollen analysis in the laboratory. For each insect species, ten specimens were used and each specimen was washed first in ethyl alcohol and the contents stained with anilineblue on a glass slide for observation under a microscope to count the number of pollen grains present. In case of pollen-collecting bees, the pollen loads on their corbiculae were separated prior to washing them. From pollen counts, the average number of pollen grains carried by bees and the wasp was calculated to determine their pollen carryover efficiency. The snails were also collected after flower visits and body washings were done to count the pollen present on each individual. A beetle was found to be a flower predator. A sample of five hundred flowers collected from different flowering patches was used for calculating the flower predation rate by this beetle.

Photography: Plant, flower and fruit details, together the foraging activity of foragers, were photographed with a Nikon D40X Digital SLR (10.1 pixel) and TZ240 Stereo Zoom Microscope with SP-350 Olympus Digital Camera (8.1 pixel). Magnus Compound Microscope - 5x, 10x, 40x and 100x 
magnification was used for studying the pollen characteristics.

\section{Results \\ Phenology: The plant is a trailing, glabrous, perennial creeper with deeply-lobed leaves; this species is an important constituent of the local beach vegetation and occurs landward into mangroves. It usually colonizes the sandy areas with its creeping habit; an excellent sand- binding species, Ipomoea pes-caprae plays an important role in sand accretion on the beaches and in binding soil along the margins of mangrove vegetation. It usually forms pure stands. Leaf flushing and new growth occur during the early rainy season from June to September with flowering from August to February with peak flowering during November and December (Fig. 1). Flowers are axillary, solitary or in few-flowered cymes; in the latter case, they open over a period of two or three days. The flowers are nearly erect, are positioned above the foliage, and are prominent even from a long distance.}

The flower: The flowers are pedicellate, large (70 $\mathrm{mm}$ long and $68 \mathrm{~mm}$ wide), showy, bisexual, and actinomorphic. The calyx is green with five ovate to elliptic sepals (20 mm long), these are united at the base and free at the distal end. The corolla is gamopetalous, $60 \mathrm{~mm}$ long, five-lobed distally, and funnel-shaped narrowing towards the base; its colour ranges from pink to red-purple or violet. The colour is darker at the inside base. The stamens are five, white, epipetalous, arising at the base of the corolla, and unequal in length; the filaments of all stamens are hairy with dithecous, introrse and basifixed anthers. The ovary is bicarpellary, bilocular, and syncarpous with a total of four ovules on axile placentation. The style is white, $12 \mathrm{~mm}$ long, and terminating by a bilobed, wet stigma (Fig. 3A).

Floral biology: The mature flower buds open daily over a fairly short period of time from 07:00-08:00 h (Fig. 2A-F). Anther dehiscence takes place by longitudinal slits within $30 \mathrm{~min}$ after anthesis. The pollen output per anther is $2,556 \pm 126.3$ (Range 2,384-2,825) or 12,780 \pm 492.8 (Range 11,920-14,125) per flower. The pollen grains are white, ellipsoidal, spinous, sticky, and are $86.3 \pm 10.4 \mu \mathrm{m}$ in size. The pollen: ovule ratio is $3,195: 1$. A large circular nectary disc located at the base of the ovary secretes nectar throughout the morning until noon, producing a total of volume of $5.2 \pm 0.6$ $\mu \mathrm{l}$ with a sugar concentration of $35 \pm 2.8 \%$. The deeply lobed leaves produce extra-floral nectar from a pair of glands on each petiole near the point of blade attachment. Nectar is produced from red nectaries on young leaves that turn black on old leaves. The stigma is situated midlevel to the anthers of long stamens (Fig. 3B). The lobes are wet, viscid and shiny in sunlight, and are receptive to pollen an hour after anther dehiscence. The receptivity continues until 16:00 $\mathrm{h}$ after which the corolla closes and assumes a downward position. The corolla and stamens fall off by the noon of the following day. The style, stigma and calyx are persistent; the former remains in a dry state while the latter turns into a fruiting calyx enclosing the maturing fruit and remains so even after seed dispersal.

Breeding systems: The results of breeding systems studies indicate that the flowers are self- and cross-pollinating but self-incompatible during a post-zygotic phase. Fruit set is $10 \%$ in autogamy (unmanipulated), $16 \%$ in autogamy (manipulated), $32 \%$ in geitonogamy, and $72 \%$ in xenogamy and $8.8 \%$ in open-pollinations (Table 1). Bud and flower abortion was absent while fruit initiation in autogamy and geitonogamy modes aborted within a week; the aborted fruits could be seen as the colour of the calyx changes from a green stage in growing fruits to a light brown stage in fruits (Fig. 4A).

Table 1: Results of breeding experiments on Ipomoea pes-caprae; aborted within a week*

\begin{tabular}{lccc}
\hline \multicolumn{1}{c}{$\begin{array}{c}\text { Breeding } \\
\text { system }\end{array}$} & $\begin{array}{c}\text { No. of } \\
\text { flowers } \\
\text { pollinated }\end{array}$ & $\begin{array}{c}\text { No. of } \\
\text { flowers set } \\
\text { fruit }\end{array}$ & $\begin{array}{c}\text { Fruit } \\
\text { set } \\
(\%)\end{array}$ \\
\hline $\begin{array}{l}\text { Apomixis } \\
\begin{array}{l}\text { Autogamy* } \\
\text { (bagged) }\end{array}\end{array}$ & 50 & 0 & 0 \\
$\begin{array}{l}\text { Autogamy* } \\
\text { (hand-pollinated }\end{array}$ & 50 & 5 & 10 \\
\& bagged) & 50 & 8 & 16 \\
$\begin{array}{l}\text { Geitonogamy } \\
\text { Xenogamy }\end{array}$ & 50 & 16 & $32 *$ \\
$\begin{array}{l}\text { Open } \\
\text { pollinations }\end{array}$ & 50 & 36 & 72 \\
\hline
\end{tabular}

Pollination and Pollinators: The funnelshaped flowers, with spacious corolla tube towards its rim, expose the stamens and stigma to foragers. They were foraged consistently during day time from 07:00-15:00 $\mathrm{h}$. The foragers included hymenopterans, Apis dorsata, 
Apis cerana, A. florea, Trigona iridipennis, Xylocopa latipes, X. pubescens, Ceratina sp. (bees - Apidae), Scolia sp. (wasp - Scoliidae) and Euplecta subdecussata (snail Ariophantidae: Neogastropoda). Of these, Apis, Trigona and Ceratina bees gathered both pollen and nectar while Xylocopa bees and the Scolia wasp collected only nectar. All bee species displayed their foraging activity from 07:00 15:00 $\mathrm{h}$ while the wasp showed its activity from 07:00-13:00 h. Of the total foraging visits made by both bees and the wasp, A. dorsata and Ceratina sp. each made $14 \%$ of the visits, A. cerana and Scolia sp. 13\%, and the other bee species each made $12 \%$. Both bees and the wasp approached the flowers in an upright direction, landed on the expanded part of the corolla and then accessed the basal portion of the corolla for forage collection. These pollen collecting foragers invariably contacted the stigma and got powdered with pollen all over their dorsal and ventral side. They also had contact with the stamens and stigma while probing the flower base for nectar collection. The exclusively nectar collecting bees and the wasp also had contact with both stamens and stigma while accessing the flower base for nectar collection. Body washings of bees and the wasp revealed the presence of scores of pollen grains; the mean number varied from 295.8-756.6 (Table 2). The standing crop of nectar, despite its continuous secretion until noon, was found to be exhausted by 14:00 h. Further, most of the flowers were also found to be devoid of pollen due to the earlier hectic activity of pollen collecting bees. Since it was difficult to determine exactly what constitutes an individual plant of Ipomoea pes-caprae without damaging the plant, observations on inter-plant activity was not attempted. However, the production of only a moderate number of flowers at the population level appears to be forcing the bees and wasps to visit several widely spaced flowers in the study area. Such a foraging activity is considered to be promoting cross-pollination. All the bees and the wasp utilized the floral source throughout the duration of flowering season. The extra-floral nectaries present on the leaf petioles were never visited by foragers. Ants were also not present on the plant.

The snail, Euplecta subdecussata, was found to remain on the plant, slowly moving from flower to flower and plant to plant to collect pollen without damaging the style and stigma. It was a consistent pollen feeder throughout the flowering season and was found to be important in effecting both self- and crosspollination. Further, the beetle, Mylabris phalerata, was found to feed on floral parts including stamens and stigma; its flowerfeeding behaviour was considered to be affecting reproductive success. The flower damage and subsequent drop rate due to this beetle feeding is $47 \%$.

Table 2: Pollen pick up efficiency of foraging insects and the snail on Ipomoea pes-caprae, $n=10$

\begin{tabular}{lcc}
\hline Insect species & Range & Mean \pm S.D \\
\hline Apis dorsata & $456-678$ & $535.4 \pm 213.43$ \\
Apis cerana & $423-321$ & $377.8 \pm 91.67$ \\
Apis florea & $309-402$ & $370.0 \pm 86.35$ \\
Trigona iridipennis & $250-339$ & $295.8 \pm 78.43$ \\
Xylocopa latipes & $379-669$ & $542.4 \pm 201.6$ \\
Xylocopa pubescens & $421-723$ & $562.4 \pm 236.89$ \\
Ceratina sp. & $221-389$ & $305.5 \pm 109.23$ \\
Scolia sp. & $213-397$ & $309.1 \pm 98.27$ \\
Euplecta subdecussata & $678-872$ & $756.6 \pm 201.79$ \\
\hline
\end{tabular}

Fruiting behavior: Pollinated and fertilized flowers initiate fruit development immediately and maturation occurs within a month (Fig. 4A-D). The fruit is an ovoid-globose capsule, 15-20 mm long, initially green, then purple and finally brown. The mature and dry capsule is hard and breaks into four valves in a loculicidal manner; the breaking or dehiscence is sometimes irregular (Fig. 5A-E). The capsule contains two to four densely dark brown, pubescent, triangular seeds $6-10 \mathrm{~mm}$ long. Seeds do not undergo a period of dormancy but germinate immediately if its coat is decomposed. Still, the seed coat is impermeable to water and requires abrasion by sand prior to germination. Seeds germinate as soon as they are dispersed and abraded. Seedling establishment depends on wave action that can uproot young seedlings, accreting sands which can bury seedlings in a short time, and space competition and shading by established plants also impacts seedling establishment.

\section{Discussion}

Devall (1992) reported that Ipomoea pescaprae includes two subspecies, subsp. brasilensis (L.) Ooststr. and subsp. pes-caprae; the criteria used for this classification is that the two entities differ in the shape of their leaves and the dimensions of their calyx and corolla. The subsp. brasiliensis is pantropical except in 
the Indian Ocean area while subsp. pes-caprae is confined to the Indian Ocean. Therefore, the expression of $I$. pes-caprae observed in this study was the typical subspecies.

Ipomoea pes-caprae is a low-growing perennial trailing creeper that grows in open habitats on sandy beaches and behind sea shores along the mangrove forest margins. It is primarily considered to be a constituent of beach vegetation. In degraded mangrove patches, and along the margins of mangrove forests in Coringa, it grows well and forms large mats. Its growth in such habitats contributes to the binding and stabilization of sandy and loose soils. Further, it plays an important function of supporting the dependent local animals for their shelter, breeding and feeding. Above all, it hastens the process of sand accretion and sand dune formation. The occurrence of $I$. pescaprae in the interior areas of the shore lines and estuaries has also been reported by other workers (Jones \& Kobayashi, 1969; Devall \& Thien, 2005). Therefore, this plant may be designated as a mangrove associate.

Ipomoea pes-caprae initiates leaf flushing following monsoonal rains in June and continues until September. The flowering event commences in August and extends into February but it is mainly concentrated during November-December suggesting that complete leaf flushing and full growth of new leaves are required for profuse flowering. Devall \& Thien (1989) reported that the peak flowering period varies with geographic area; it is JulySeptember on the south Gulf of Mexico coast and South Padre Island and July-August at Grand Isle. The plants growing in protected spots on the north and south Gulf coast flower in May. Further, these authors reported that more than 3,000 flowers anthese daily in the larger populations observed by them. The present study also suggests that I. pes-caprae produces similarly large numbers of flowers daily. The plant grows in open habitats where it is exposed to bright sunshine throughout the day. The flowers, because of their position above the foliage, have the ability to function under continued sunlight and a range of ambient temperatures. Patino \& Grace (2002) experimentally proved that temperatures above the ambient natural temperatures cause pollen to be non-viable, and also causes damage to female reproductive tissue. In natural environment, the characteristic corolla shape appears to serve not only as an advertisement to attract pollinators but also as a parasol or radiation shield to maintain the female reproductive unit at its functioning temperature. In support of this, Patino \& Grace (2002) reported that the corolla has high reflectance and high conductance to water vapour. At the same time, the corolla maintains a balance between prevention of overheating and reduction of water loss. Reduction of water loss could be due to a decrease of epidermal conductance, low absorbed radiation, reduced evaporative surface by way of fused petals, and short-lived flowers. Therefore, the corolla plays dual roles, one in attraction and the second in keeping the sexual units viable and functional throughout the duration of flower-life for fruit set.

Heide (1927) provided the anthesis schedules for some Ipomoea species occurring in the East Indies. The flowers open during dawn and wither in the evening in I. carnea Jacq. and $I$. limbata (Lindl.) Linden, during the sunrisenoon period in I. tuberosa L., during 07:0008:00 $\mathrm{h}$ in I. verrucosa Blume, and at 18:00 h in I. trichosperma Blume. Victor (1999) reported that I. cairica flowers during 10:0011:00 h. Devall and Thien (1989) reported that I. pes-caprae subsp. brasiliensis undergoes anthesis during the morning but did not mention an exact schedule. All of these authors also indicated that flowers close by evening and fall off by noon of the next day. In the present study, I. pes-caprae blooms daily during 07:00-08:00 h; the corolla closes by the evening of the same day preventing visitation by foragers although it remains attached to the plant until the noon of the next day. These reported anthesis schedules suggest that most of these species are morning bloomers and adapted for pollination by day-active foragers.

In Ipomoea pes-caprae, the flowers offer both pollen and nectar as rewards to foragers. The pollen is available shortly after anthesis while the nectar is available from anthesis onwards. The nectar is secreted slowly and continuously until noon after which the nectary ceases to function. The continuous nectar secretion from anthesis to noon seems to be adapted to attract foragers for long hours and until the closure of the corolla; further, such a nectar secretion pattern enforces fidelity on the foragers to visit 
the flowers consistently during the availability period of the flowers daily and even throughout the flowering season. The nectar is secreted in moderate volume but its sugar concentration is high. Devall \& Thien (1989) also reported similar numbers in $I$. pes-capre subsp. brasiliensis in the Gulf of Mexico. The high sugar concentration has been shown to be a characteristic of bee-flowers (Baker \& Baker, 1983). In the present study, it is found that the bees, species of Apis, Trigona, Xylocopa, Ceratina, a wasp, and a snail visit the flowers for forage. Of these, bees are the principal and consistent foragers throughout the flowering season while the wasp is a frequent but not consistent forager. The Xylocopa bees and the wasp are nectar foragers while the other bees are both nectar and pollen foragers. The snail is a resident forager and consistently moves from flower to flower on the same and different plants to collect pollen without damaging or making any attempts to feed on the stigma. The field observations indicate that bees, especially Xylocopa, are principal pollinators; the body washings of these bees for pollen also substantiate this finding. The snail is also important in both self- and cross-pollination and its body washings for pollen also conform this. Therefore, I. pes-capre is both melittophilous (bee-pollination) and malacophilous (snail-pollination), sensu Faegri \& van der Pijl (1979). Knuth (1904) observed that I. pes-caprae is pollinated by Apis and Scolia and suggested that Xylocopa bees are also appropriate foragers of this plant species. In areas around the Gulf of Mexico, I. pescaprae subsp. brasiliensis has been reported to be pollinated by a guild of hymenopterans consisting of bees, butterflies, moths, flies, beetles, wasps, and ants but of these bees have been shown to be the primary pollinators since they used this floral source consistently (Devall \& Thien, 1989). In another study, Devall \& Thien (1992) showed that Xylocopa bees are the primary pollinators of this subspecies and they have the ability to disperse pollen up to 90 m. Van der Pijl (1954) described the foragers of some Ipomoea species. For example, I. crassicaulis (Benth.) B.L. Rob. with pale-violet flowers is pollinated by species of Xylocopa; these bees do not prefer this floral source in the presence of Thunbergia grandiflora Roxb. He also mentioned that I. nil, I. reptans Poir. and I. pes-caprae represent bee-flowers. Burkill (1916) noted that I. batatas (L.) Lam. and I. rubro-caerulea Hook. are pollinated by anthophorid bees while $I$. digitata $\mathrm{L}$. is pollinated by Xylocopa latipes and $I$. paniculata Burm.f. by $X$. aestuans. Melittophily has been reported in $I$. kentrocaulos C.B. Clarke (Subba Reddi \& Reddi, 1982), I. triloba L., I. setifera Poir., I. batatas, I. carnea (Frey, 1995), and I. cairica (Victor, 1999). These reports suggest that the Ipomoea species studied so far are melittophilous and among the bees, species of Xylocopa are principal pollinators. Therefore, Ipomoea appears to be primarily melittophilous.

In Ipomoea pes-caprae, snail-pollination is equally important as bees and wasps. The prostrate and twining habit and floral arrangement in which the stigma and anthers do not extend much beyond the corolla appear to be conducive for snail-pollination (Pammel \& King, 1930). The effective malacophily observed in this species refutes the doubts expressed by Faegri \& van der Pijl (1979) and by Atwood (1982) that malacophily is not effective or obscure or even ridiculous. Malacophily in I. pes-caprae is the second report for Convolvulaceae and the first report for Ipomoea. Further, malacophily is also reliable since snails are associated with beach sand and sea water while melittophily is much less reliable due to the prevalence of high wind speeds most of the time along the shoreline or estuarine zone.

In Ipomoea crassicaulis the nectar is secreted in minute volume and hidden in the basal part of the flower tube behind the broad bases of the filaments which act as obstacles. But, this location is not so protective as to prevent nectar thievery and hence the hard calyx below gives extra-protection. Despite this protection, Xylocopa latipes resort to burglary to collect nectar by puncturing the corolla tube (Knuth, 1904). In I. digitata the nectar is protected by a hardened basal corolla tube and inflated calyx with extremely firm sepals (Burkill, 1916). Nectar thievery by $X$. latipes has also been reported in I. carnea and I. limbata (Heide, 1927). In the present study, Xylocopa bees have never been found to be resorting to nectar thievery of $I$. pes-caprae as the flower is spacious and provide easy access to the nectar location, so there is no need for these bees to practice thievery. 
Elias (1983) reported that Ipomoea species have extra-floral nectaries on lower leaf surfaces, petioles, and pedicels just below the junction with sepals. Their presence has been reported in I. carnea, I. biloba, I. batatas, I. bona-nox, I. leptophylla, I. pandurata, and $I$. tuberosa. Devall \& Thien (1989) reported that I. pes-caprae subsp. brasiliensis also has extrafloral nectaries on leaf petioles and attract ants and other visitors. In $I$. pes-caprae at the present study site, extra-floral nectaries are present on the leaf petioles and nectar is secreted in traces. But, these nectaries are not visited by any insect species including ants. This suggests that their presence does not serve the purpose of attracting certain visitors which subsequently move to flowers to collect the forage and effect pollination.

Devall \& Thien (1992) reported that Ipomoea pes-caprae subsp. brasiliensis is selfincompatible since self-pollinated flowers produce few or even inviable seeds. The high pollen:ovule ratio and the most efficient pollinator bees, Xylocopa, have been shown to be adaptive characteristics for maximizing outcrossing. In the present study, I. pes-caprae is also self-incompatible but incompatibility is functional only during the post-zygotic stage. Self-pollination occurs due to weak protandry and the placement of its anthers close to the stigma so that pollination can occur with and without the involvement of pollinators. The self-pollinated flowers initiate fruit development but subsequently fruit growth ceases; the persistent green-coloured fruiting calyx seen in initial fruit growth turns brown, withers and eventually falls off suggesting that self-pollinated flowers do not reach a seed setting stage. The natural fruit set rate does not exceed $10 \%$ despite the high pollen:ovule ratio and hectic pollinator activity of bees and also the snail. This low fruit set could be attributable to a combination of factors: the wastage of pollen in self-pollination, ephemeral nature of flowers, and the heavy flower predation by the beetle, Mylabris phalerata. Field observations also indicate that the pollen of this plant seems to be the principal food source for the young snails of Euplecta subdecussata and hence is an important pollinator. Devall \& Thien (1992) reported that the flowers of I. pes-caprae subsp. brasiliensis have no chemical defenses and are routinely eaten by caterpillars, beetles and grasshoppers. In the present study, the flowers of I. pes-caprae are eaten only by Mylabris suggesting that its flowers may have some chemical defenses to repel or prevent feeding by other insects.

In the present study, fruits of Ipomoea pescaprae mature quickly and each fruit contains two to four seeds. The seed set rate at fruit level could be relatable to fertilization rate of ovules in pollinated flowers, pollen source (self- or cross-pollination), and the nutritional state of the sandy soil environment. The mature fruits dehisce to disperse seeds and the latter are moved about by wind-blown sands. The seeds are impermeable to water and not dormant; they germinate readily if they are covered and abraded by sand while those that are exposed to seawater rot and subsequently perish (Devall \& Thien, 1992). The low natural fruit set rate, the mortality of seeds and seedlings due to rotting by sea water, burial by sand, competition for space, and shading by established plants appear to be regulating the population size of the plant (Devall, 1992). The plant also propagates vegetatively through the expansion of branches that are broken into fragments by storm waves, transported by water, and then washed onshore into new locations. Vegetative propagation has been reported in I. pes-caprae subsp. brasiliensis by Devall (1992). The dual reproductive modes functional in both subsp. pes-caprae and subsp. brasiliensis allow them to colonize and expand population to the extent possible in their available environments.

\section{Recommendations}

Ipomoea pes-caprae as a mangrove associate shows extensive growth and covers the landward floor of the mangrove forest as well as undisturbed beaches. This plant, with it hermaphroditic sexual system and post-zygotic self-incompatibility, is able to set fruit through vector-mediated pollination. The flowers are both melittophilous and malacophilous. The seeds are impermeable to water and not dormant; they germinate readily if they are covered and abraded by sand while those which are exposed to seawater rot and subsequently perish. The low natural fruit set rate, the mortality of seeds and seedlings due to rotting by sea water, burial by sand, space constraint, and shading by established plants appear to be regulating the population size of the plant. Ipomoea pes-caprae also propagates vegetatively through the expansion of branches 
that are broken into fragments by storm waves, transported by water, and then washed onshore into new locations. Therefore, this species, with its dual modes of reproduction, is able to populate by itself and in this context it is important to take effective measures for its protection due to its sand-binding properties that stabilize the landward mangrove areas, beaches, and for its food value for insects and snails.

\section{Literature cited}

Atwood, Jr., J., 1982. How is Paphiopedilum pollinated? American Orchid Society Bulletin, 51: 1057-1058.

Austin, D. F., 1997. Dissolution of Ipomoea series Anisomerae (Convolvulaceae). Journal of the Torrey Botanical Society, 124: 140-159.

Austin, D. F., 2004. Florida Ethnobotany. CRC Press: 365.

Baker, H. G. and I. Baker, 1983. A brief historical review of the chemistry of floral nectar. Pp. 126-152. In: Bentley, B. and T. Elias (eds.). The Biology of Nectaries. Columbia University Press, New York.

Britta, T., K. Macki, W. Ludger, H. Thomas, and E. Eckart, 1999. Occurrence of loline alkaloids in Argyreia mollis (Convolvulaceae). Phytochemistry, 51: 1177-1180.

Burkill, I. H., 1916. Notes on the pollination of flowers in India. Note No. 8, Miscellanea. Journal \& Proceedings of Asiatic Society of Bengal, 12: 239-265.

Cruden, R. W., 1977. Pollen-ovule ratios: A conservative indicator of breeding systems in flowering plants. Evolution, 31: 32-46.

Dafni, A., P. G. Kevan, and B. C. Husband, 2005. Practical Pollination Biology. Enviroquest Ltd., Ontario: 590

Devall, M. S., 1992. The biological flora of coastal dunes and wetlands. 2. Ipomoea pescaprae (L.) Roth. Journal of Coastal Research, 8: 442-456.

Devall, M. S. and L. B. Thien, 1989. Factors influencing the reproductive success of Ipomoea pes-carprae (Convolvulaceae) around the Gulf of Mexico. American Journal of Botany, 76: 18211831.
Devall, M. S. and L. B. Thien, 1992. Selfincompatibility in Ipomoea pes-caprae (Convolvulaceae). American Midland Naturalist, 128: 22-29.

Devall, M. S. and L. B. Thien, 2005. Inland occurrence of the strand plant Ipomoea pescaprae (Convolvulaceae) around Lake Nicaragua. The Southern Naturalist, 50: 380-384.

Elias, T. S., 1983. Extrafloral nectaries: Their structure and distribution. Pp. 174-203. In: Bentley, B. and T. Elias (eds.). The Biology of Nectaries. Columbia University Press, New York.

Faegri, K. and L. van der Pijl, 1979. The Principles of Pollination Ecology. Pergamon Press, New York: 248.

Frey, R., 1995. Flora and vegetation "Las Piedritas" and the margin of Laguna Caceres, Puerto Suarez, Bolivian Pantanal. Bulletin of the Torrey Botanical Club, 122: 314-319.

Heide, F., 1927. Observations on the pollination of some flowers in the Dutch East Indies. Dansk Botanisk Arkiv, 5: 1-42.

Hull-Sanders, H. M., M. D. Eubanks, and D. E. Carr, 2005. Inbreeding depression and selfing rate of Ipomoea hederacea var. integriuscula (Convolvulaceae). American Journal of Botany, 92: 1871-1877.

Jones, A. and M. Kobayashi, 1969. Derived polyploids of section Batatus genus Ipomoea. Proceedings of the American Society for Horticultural Science, 93: 487-501.

Knuth, P., 1904. Handbuch der Blütenbiologie. Vol. 3, Wilhelm Engelmann, Leipzig: 598.

Maimoni-Rodella, R. C. S. and Y. A. N. P. Yanagizawa, 2007. Floral biology and breeding system of three Ipomoea weeds. Planta Daninha, 25: $35-42$.

McGregor, S. E., 1976. Pollinating agents and their comparative value. In: McGregor, S. E (ed.). Insect pollination of cultivated crop plants. U.S.D.A. Agriculture Handbook, 496: 19-23.

Pammel, L. H. and C. M. King, 1930, Honey plants of Iowa. Iowa Geological Survey Bulletin, 7: 892-894. 
Patino, S. and J. Grace, 2002. The cooling of convolvulaceous flowers in a tropical environment. Plant, Cell \& Environment, 25: 4151.

Ravindran, K. C., K. Venkatesan, V. Balakrishnan, K. P. Chellappan, and T. Balasubramanian, 2005. Ethnomedicinal studies of Pichavaram mangroves of East coast, Tamil Nadu. Indian Journal of Traditional Knowledge, 4: 409-411.

Reddi, C. and E. U. B. Reddi, 1982. The pollination biology of Ipomoea kentrokaulos (Convolvulaceae). Indian Botanical Reporter, 1: $1-4$.

Sarma. K., R. Tandon, K. R. Shivanna, and H. Y. Mohan Ram, 2007. Snail pollination Volvulopsis nummularium. Current Science, 93: 826-831.

Steiner, U., M. A. Ahimsa-Muller, A. Markert, S. Kucht, J. Grob, N. Kauf, M. Kuzma, M. Zych, M. Lamshoft, and M. Furmanowa, 2006. Molecular characterization of a seed transmitted clavicipitaceous fungus occurring on dicotyledonous plants. Planta, 224: 533-544.

Suvarna Raju, P., P. Hareesh Chandra, Rajendra Kumar, and A. J. Solomon Raju, 2013. Pollination ecology of Ipomoea tuba (Schltdl.) G. Don (Convolvulaceae). Advances in Pollen Spore Research, 31: 41-50.

Van der Pijl, L., 1954. Xylocopa and flowers in the Tropics. I-III. Proceedings of Koninklijke Nederlandse Akademie van Wetenschappen, ser. C, 57: 413-423, 514-562.

Victor, P., 1999. The Floral Ecology of Some Tropical Plant Species. Unpublished doctoral dissertation, Andhra University, Visakhapatnam.

Willmott, A. P. and A. Burquez, 1996. The pollination of Merremia palmeri (Convolvulaceae): Can hawk moths be trusted? American Journal of Botany, 83: 1050-1056. 


\section{PLATE 7}

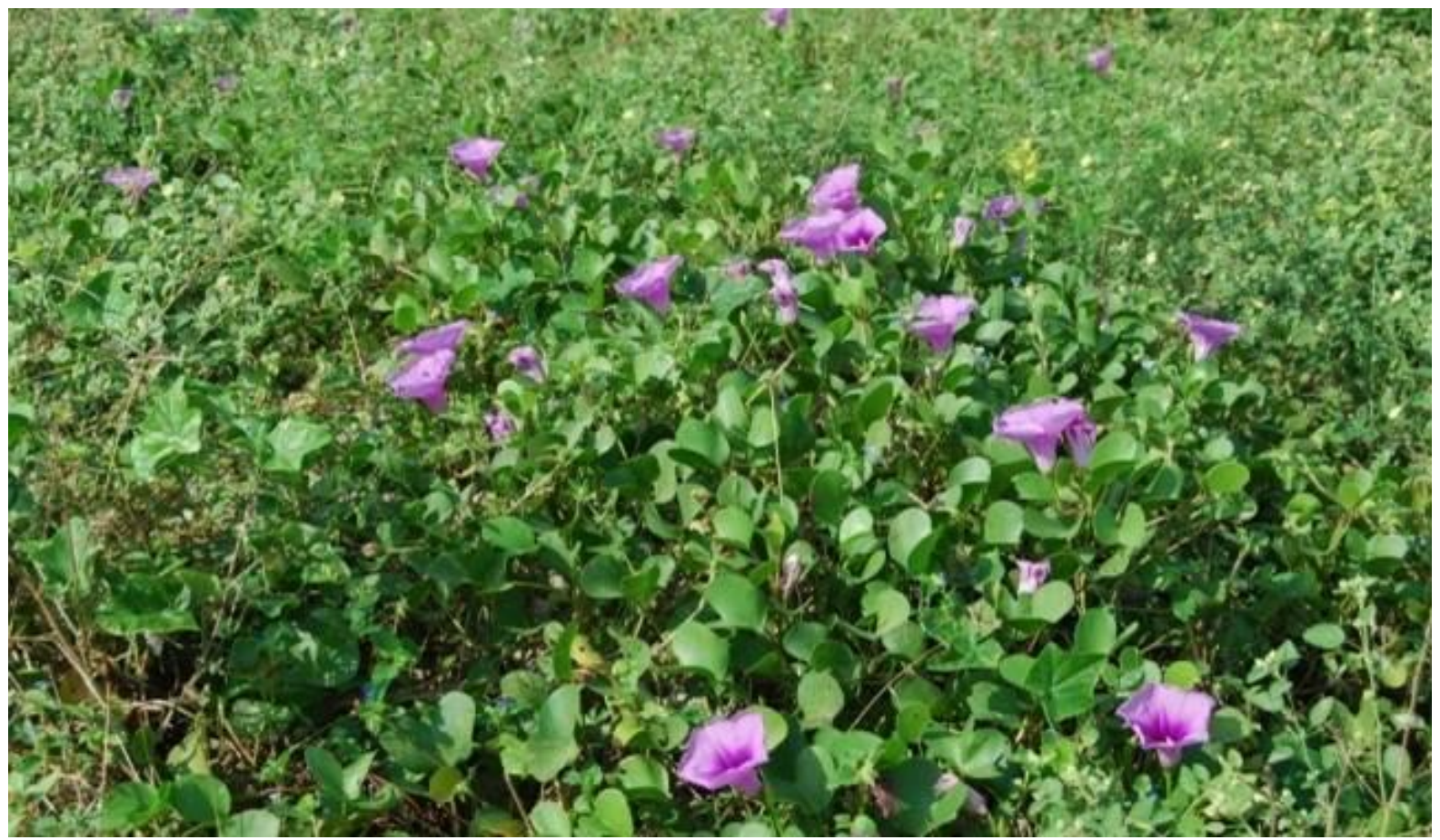

Figure 1: Ipomoea pes-caprae habit with lowering.
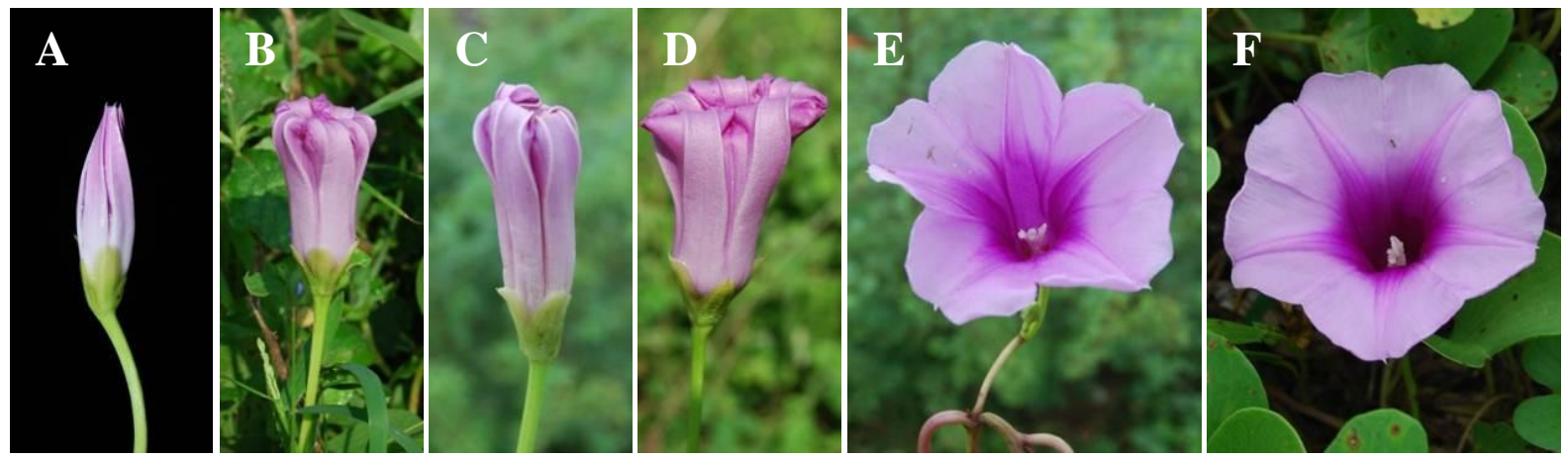

Figure 2: A-F, Ipomoea pes-caprae different stages of anthesis
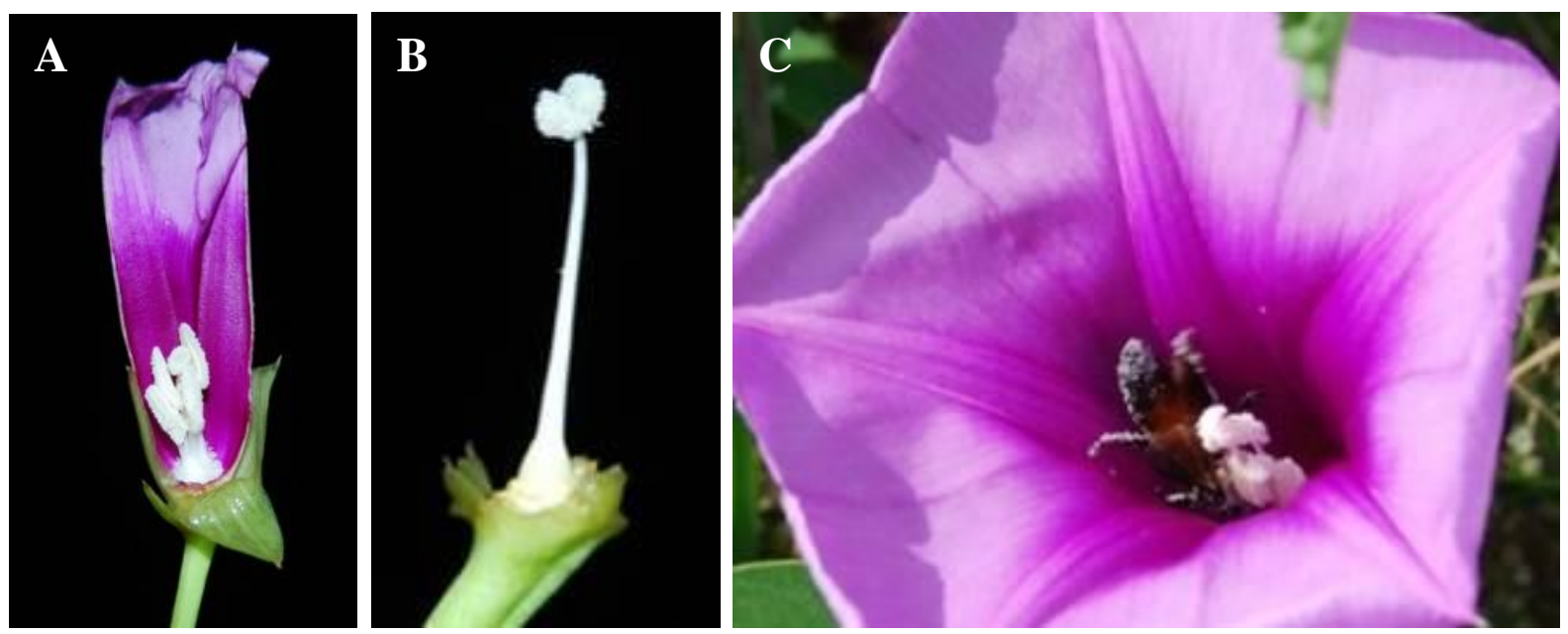

Figure 3: Ipomoea pes-caprae A, ovary, style and stigma; $\mathbf{B}$, cut flower showing the position of stamens and stigma; C, Apis dorsata collecting nectar from the flower. 


\section{PLATE 8}
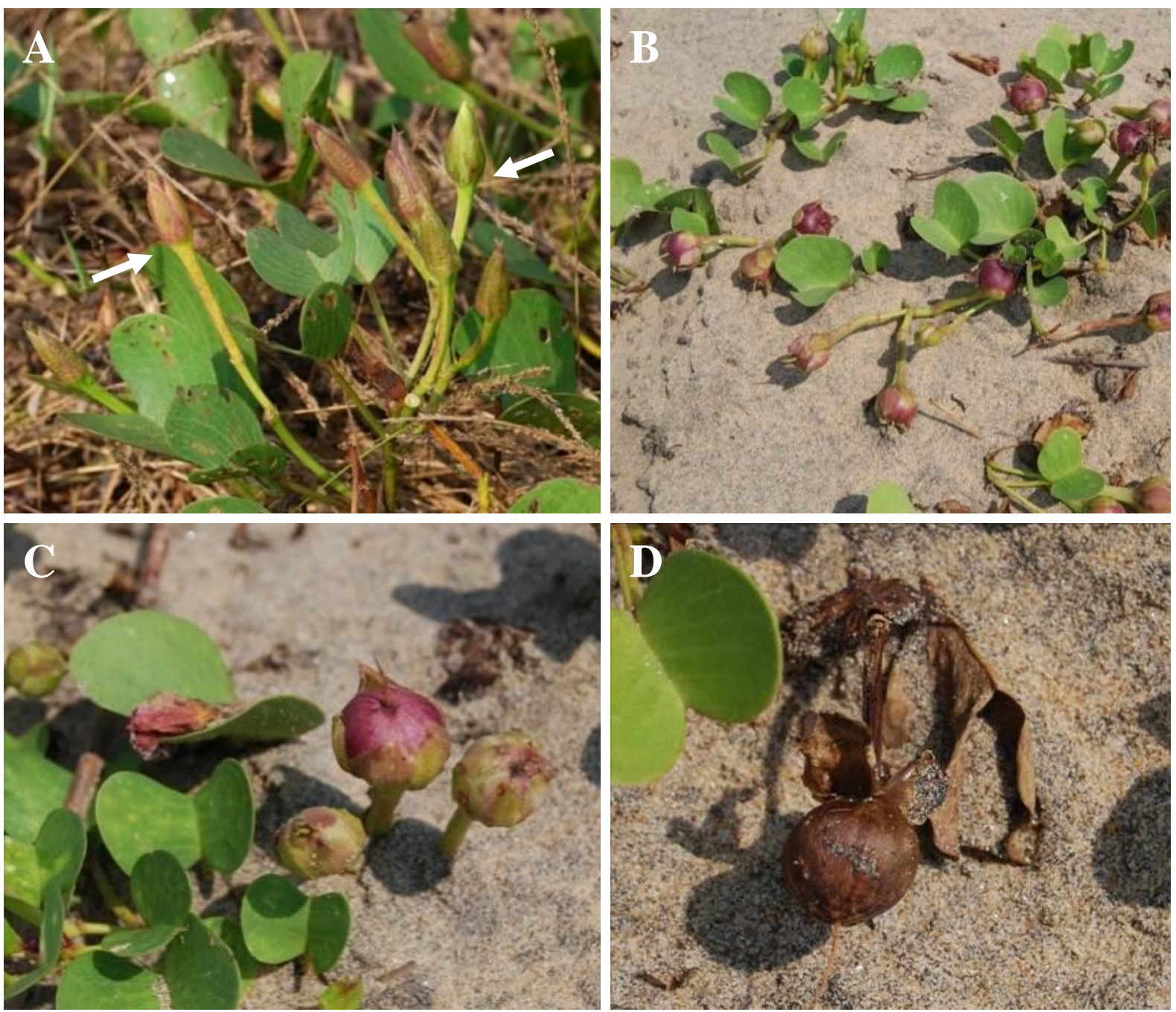

Figure 4: Ipomoea pes-caprae A, Fruit abortion (left arrow) and fruit initiation (right arrow); B, growing fruits; $\mathbf{C}$, mature fruits; $\mathbf{D}$, dry fruit
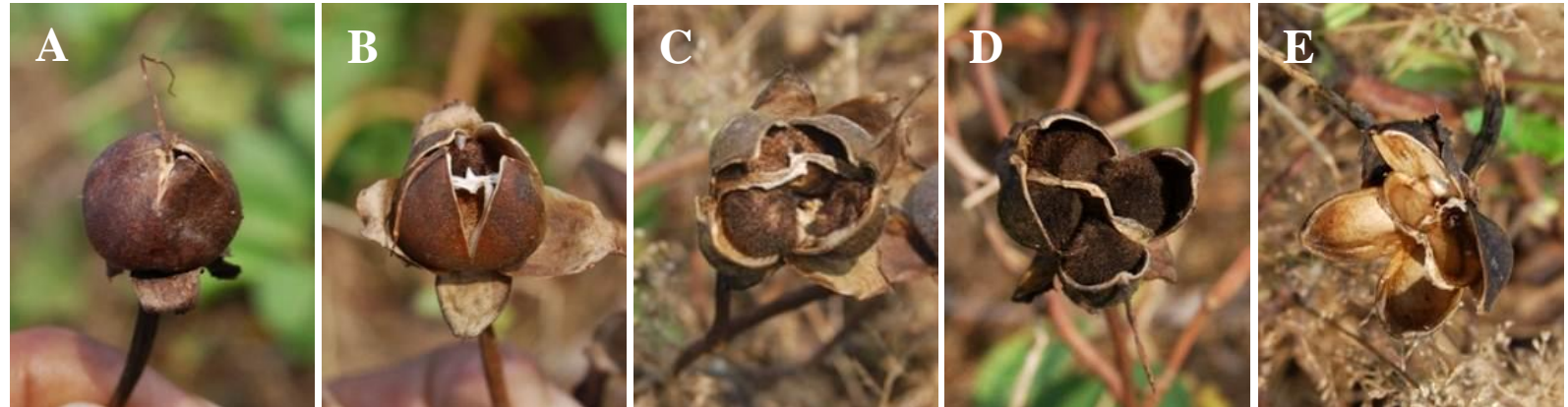

Figure 5: Ipomoea pes-caprae A-E, different stages of fruit dehiscence 